injure the forest industries, and conditions which might tend to encourage these industries and keep them profitable. These matters will be brought to the attention of the provincial government and support for this great industry will be sought from the public.

(Canadian Lumberman, September 1, 1943)

\title{
TORONTO FORESTER IN NORWAY
}

The students in the Faculty of Forestry at the University of Toronto around 1925-29 will be interested to know that Dr. C. D. Howe has recently. received through the International Red Cross the following message from Frithjof Plahte, '29:

"Dear Dr. Howe-Asta and I send you and your family our heartiest greetings. We are well here. Please remember me to my friends."

The message was filed in Terrok, March 8, stamped in Oslo, March 17, and stamped in Geneva, May 4, 1943. It was received in Toronto, October $14,1943$. 